\title{
Impacts of Terrorism and Piracy on Maritime Activities: An Exploratory Study
}

\author{
Donatus Eberechukwu Onwuegbuchunam ${ }^{1}$, Kenneth Okechukwu Okeke ${ }^{1}$, \\ Moses Olatude Aponjolosun ${ }^{1}$, Chinemerem Igboanusi ${ }^{2}$ \\ ${ }^{1}$ Department of Maritime Management Technology, Federal University of Technology, Owerri, Nigeria \\ ${ }^{2}$ Department of Transport Management Technology, Federal University of Technology, Owerri, Nigeria
}

Email address:

don@futo.edu.ng (D. E. Onwuegbuchunam)

\section{To cite this article:}

Donatus Eberechukwu Onwuegbuchunam, Kenneth Okechukwu Okeke, Moses Olatude Aponjolosun, Chinemerem Igboanusi. Impacts of Terrorism and Piracy on Maritime Activities: An Exploratory Study. International Journal of Transportation Engineering and Technology. Vol. 7, No. 4, 2021, pp. 104-109. doi: 10.11648/j.ijtet.20210704.13

Received: September 2, 2021; Accepted: September 22, 2021; Published: November 25, 2021

\begin{abstract}
The international community is paying more and more attention to the activities of terrorists and pirates, which have greatly hindered the flow of international seaborne trade and other maritime activities. Many national governments have implemented certain security policies to address the twin problem of terrorism and piracy with minimal results achieved. The researchers propose that policy effective response models for addressing these security problems must be based on quantitative analysis of impacts of terrorism and piracy on the affected maritime domain. This paper assessed impacts of terrorism and piracy on maritime related economic activities in Niger Delta region of Nigeria. The data for this study comprised volume of crude oil production, quantity of crude oil in tanker vessels lost to terrorism acts and the quantity of fish catch/production over a period of fifteen years (2000-2015). We employed Linear Regression Analysis model to determine significant correlations between pairs of economic variables in the study. Findings showed that significant inverse relationship exists between the selected maritime related economic activities and acts of maritime terrorism and piracy. Policy implications of the results were discussed.
\end{abstract}

Keywords: Terrorism/Pirate Attack, Maritime Activities, Crude Oil Production, Crude Oil Losses, Fish Production

\section{Introduction}

Until recently there have only been a few reported incidences of maritime terrorism in Nigerian waters. Maritime terrorism has become a serious threat to maritime security since ocean going vessels, offshore oil platforms and gas plants as well as oil workers are often the target. Terrorism poses a great risk to high-value manufactured goods transported between global economic centres including Nigeria. The oil industry and other maritime sectors have been severely affected by these activities in the Niger Delta region of Nigeria. Despite Oil companies having armed escorts, militants often outgun them and casualty has been high. Also in recent times, blowing of oil pipeline and gas plant by Niger Delta Avengers has crippled maritime activities and power (electricity) generation in Nigeria.

\subsection{Statement of Problem}

In recent years, maritime terrorism has become a reoccurring event in Nigeria coastal and internal waters since the emergence of militancy in the Niger Delta region. The Federal Government of Nigeria has employed several approaches to tackle the problem. Apart from direct use of force by both the Nigerian Army and Navy; the government has sought the cooperation of countries within the African sub-region for deployment of regional force against maritime insecurity. Yet it appears that not much has been achieved to mitigate the incidence. Recent bombing of oil pipelines, gas plants as well as watercraft by Niger Delta Avengers (NDA) have negatively impacted maritime activities in particular, investment and economy at large. Concerned with evaluation of economic impacts of maritime insecurity on the maritime domain as basis for more responsive policies, this paper evaluates significant effects of incidences of acts of terrorism 
and pirate's attacks on volume of crude oil production, quantity of crude oil lost from tanker vessels, and quantity of fish production in Nigeria's Niger Delta region.

\subsection{Objectives of Study}

The aim of this work is to assess the effects of incidence of maritime terrorism and piracy on the maritime activities in Nigeria. The specific objectives are:

1. To assess significant effects of incidence of terrorism and piracy on the volume of crude oil production in Nigeria.

2. To determine significant effects of incidence of terrorism and piracy on the number of crude oil lost from tankers that lift oil from Nigeria.

3. To determine significant effects of incidence of terrorism and piracy on level of fish production in Nigeria.

\section{Conceptual and Literature Review}

Maritime terrorism and piracy are terms used to describe violent acts carried out by malevolent actors operating at sea. They are two aspects of the larger phenomenon of maritime insecurity [6] which pose enormous risks to global markets [3]. According to Nelson [8], maritime terrorism and piracy are two completely different phenomena, because the perpetrators of these acts have different motives and choose targets according to different objectives. Maritime terrorism may be committed to achieve political advantage while piracy may be committed primarily to achieve economic gains. Pirates only demand ransoms and never make political demands (Shotland \& Vothknecht, 2011) unlike terrorists. Although, the motive behind piracy and maritime terrorism differs [4] however, terrorists could use similar methods as that of pirates for achieving their goals i.e. to destabilize maritime security [5]. Therefore, there is need for policymakers to first understand the nature and conditions that give rise to piracy and maritime terrorism in order to develop and implement the most effective and efficient counterstrategy. Additionally, to mitigate the threats, effort should be made to understand whether these acts are local, regional, or global threats [8]. Certain factors favour the acts of piracy and maritime terrorism attacks at sea. These are legal and jurisdictional opportunities, geographical necessity, inadequate security, secure base areas, maritime tradition, charismatic and effective leadership, state support and promise of reward [7]. However, Murphy [7] states that targets that are chosen by terrorists fall into four categories: Ships as iconic targets; Ships as economic targets; Ships as mass casualty targets and ships as weapons. Moreso, terrorists often use small boats to carry out attacks against unsuspecting ships. Similar to pirates, terrorists prefer small boats because of their speed and acceleration, maneuverability and ability to evade radar detection [7].

Essien and Adongoi [2] examined sea piracy and security challenges of maritime business operation in Nigeria and established that sea piracy has a significant negative effect on shipping activities. Hence, adequate security should be provided for shipping activities so as to facilitate sea business operation in Nigeria. Udensi et al. [12] examined the severity and pattern of piracy in Nigeria's waterways and found that although corruption is the main cause of piracy and insecurity in Nigeria, election fraud directly or indirectly provided weapons to pirates. Donna [1] states that maritime terrorism in Nigeria is directly linked to oil development which results in economic, social and environmental conditions in the Niger Delta. For example, pollution from oil-production facilities has decimated local fisheries and farmland and gas flaring has caused chronic respiratory problems, especially among children. For example, pollution from oil production facilities destroy local fisheries and farmlands and gas flaring has led to chronic respiratory problems, especially in children. Thus agitations for better environment conditions and employment which remain largely unaddressed by the government often lead to terrorists' acts and piracy of maritime nature in the Niger Delta regions.

Although the extent of threats from maritime terrorism has increased significantly in recent years [9], piracy is more common and frequent than Maritime terrorism (Singha, 2019). However, it is pertinent to note that the costs of maritime piracy to Nigerian society and the economy have been significant, not only to the oil industry, but to local fisheries and regional trade as well. Due to pirate attacks on ships and other incidents, Nigeria's oil production has fallen by $20 \%$ since 2006 [1]. He further stated that piracy and other illegal maritime activities cost the Nigerian economy \$202 million between 2005 and 2008. A recent report commissioned by Royal Dutch Shell estimated that $10 \%$ of Nigeria's daily oil production (approximately 100,000 barrels) is stolen. This value is approximately US $\$ 1.5$ million which would be enough to purchase arms and ammunition to sustain a robust combat capacity of 1,500 people for two months. In the last fifty years, the value of oil stolen or wasted has ranged from $\$ 30$ billion to $\$ 400$ billion. Although most of this cost is borne by the oil companies and the federal government, the loss of revenue also means a reduction in the social and economic development needed for the Niger Delta region.

Maritime terrorism act has also caused huge losses to the country's important local fishery economy. Fishing is Nigeria's second largest non-oil export industry and pirate attacks on trawlers have recently increased [1]. The Nigerian Maritime Security Task Force on Illegal Activities in Nigerian Waters (IAMSTAF) reported that between 2003 and 2008, there were at least 293 maritime thefts and piracy attacks on fishing vessels in the country alone. The International Maritime Bureau (IMB) reported 177 attacks during these years. The attacks ranged from minor harassment to the theft of fish, engines and other materials onboard ships, economic ransoms and the killing of fishermen. As of March 2008, more than 170 trawlers were inactive, threatening approximately 50,000 jobs because fishing vessels operators were afraid to sail at sea. In addition 
to the impact on Nigeria's export economy, the price of seafood has skyrocketed due to a shortage of fish as a result of fewer fishing vessels willing to sail. In some places, prices have doubled or even quadrupled, making this important source of protein beyond the affordability of most ordinary citizens.

Given the foregoing, there is need for adequate policy intervention to curb maritime terrorism and piracy acts. This calls for assessment of significant relationship between incidences of maritime terrorism/piracy and major maritime activities like crude oil production, crude oil losses and fishing which constitute the mainstay of Nigeria's economy.

\section{Methodology}

This paper adopted a survey approach to analyse historical data on reported cases of maritime terrorism and piracy attacks on some selected economic activities in the Niger Delta region in Nigeria. The maritime related economic activities include volume of crude oil produced offshore, quantity of crude oil in tanker vessels lost to terrorism and fish production. The secondary data on these variables (for the period from 2000-2015) were obtained from annual reports of the Nigerian National Petroleum Corporation (NNPC) Lagos, Nigerian Port Authority (NPA) Lagos and the International Maritime Bureau (IMB). The main hypothesis governing this paper is the postulation that security problems emanating from terrorism and piracy impact maritime economic activities vis: crude oil production, crude oil loses from tanker shipping operations and fishing. Therefore, to test for significant relationship between crude oil production volume, crude oil lost from tankers and quantity of fish production and incidences of maritime terrorists/pirate attacks over the study period, a statistical linear regression model was adopted. The relationship between each of the dependent variables and the independent variable is linear and can be postulated as shown:

$$
\mathrm{Y}_{\mathrm{it}}=\beta_{0}+\beta_{\mathrm{i}} \mathrm{X}_{\mathrm{it}}+\varepsilon_{\mathrm{it}}
$$

Where

$\mathrm{Y}_{\mathrm{i}}$ : dependent variable,

Where: $\mathrm{I}=1,2,3$ and

$\mathrm{y}_{1}$ : Vol. of crude oil_prod;

$\mathrm{y}_{2}$ : Vol. of crude oil lost;

$\mathrm{y}_{3}$ : Qty of fish_prod; and

$\mathrm{X}_{\mathrm{t}}$ : incidence of maritime terrorist/pirate acts in year $\mathrm{t}$

$\beta_{0}$ : intercept term,

$\mathrm{t}=$ years $(2000-2015)$

$\varepsilon_{i t}=$ the error term and capture error by the researcher owing to measurement and other omitted variables. The subscript t represent the years (2000 to 2015).

\section{Data Presentation and Analysis}

The Distribution of crude oil production output (Y1), volume of crude oil in tankers lost in attacks (Y2), fish production output (Y3) and number of terror/pirate attacks (X) over the study period are shown in table 1 .

Table 1. Crude Oil Production Output, Crude Oil Losses (from Tanker Vessels), Fish Production and Reported Cases of Terror/Pirate Attacks (2000-2015).

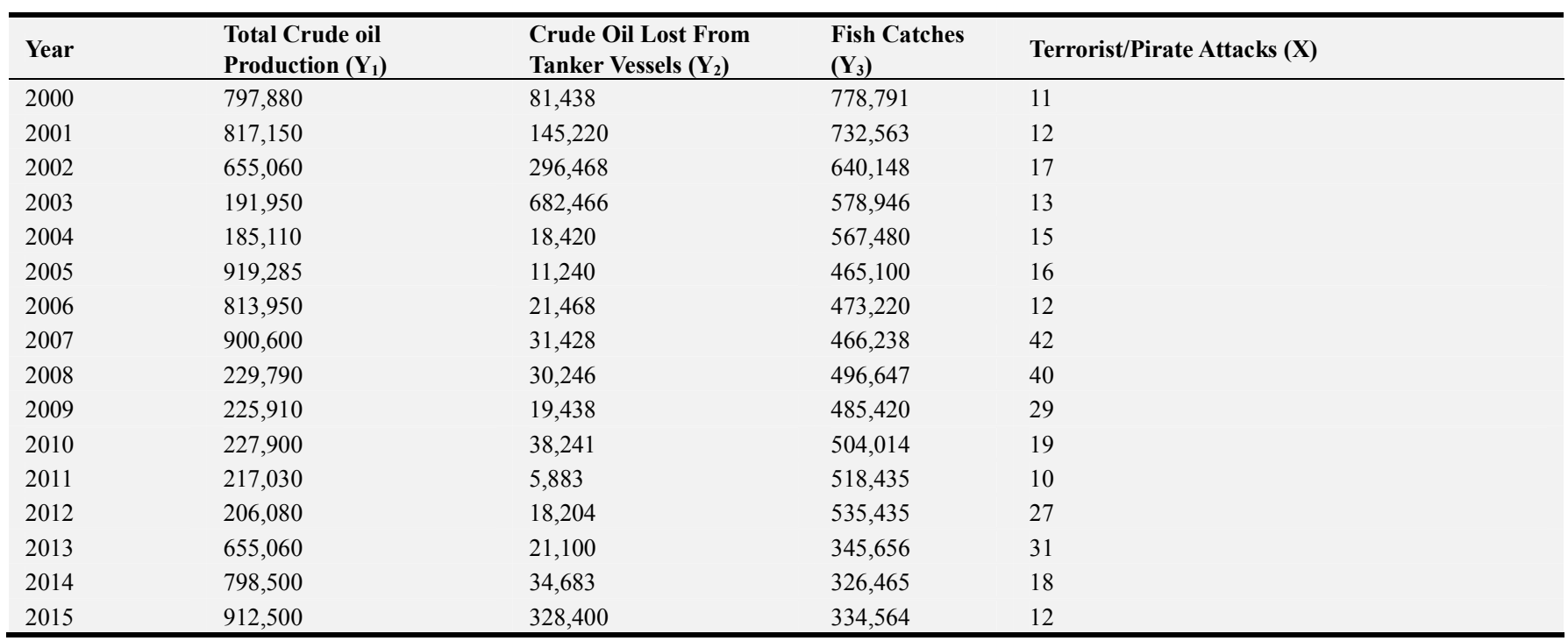

Source: NPA, NNPC, IMB (2016).

Analysis of trends over time indicates dissimilarities in patterns among the variables under study. For example, except for marginal growth observed in year 2011-2012, fish production output showed gradual but steady decline since the year 2000, see figure 1. However, outputs from crude oil production and quantity of crude oil in tankers lost to attacks maintained steady rise after trough and peaks observed from years 2000 to 2008 . 


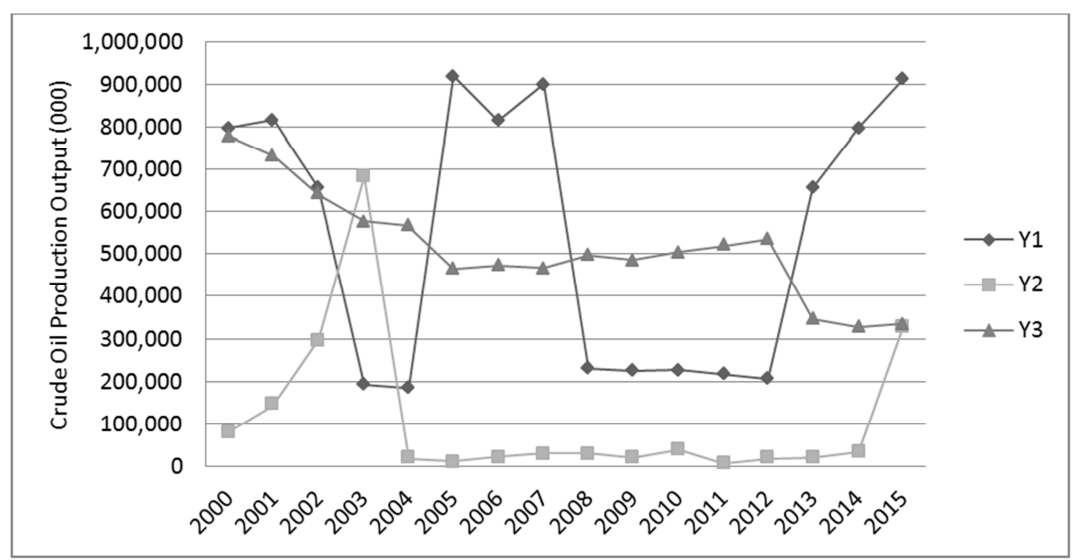

Figure 1. Trends in Crude Oil Production (Y1), Crude Oil Loses (Y2) and Quantity of Fish Caught (Y3).

The incidence of terror and pirate attacks (X) has followed erratic pattern since the year 2000, dropping in years 2006 and 2011 and rising to highest levels in years 2008 and 2013, see figure 2. However, X has maintained steady decline through year 2013.

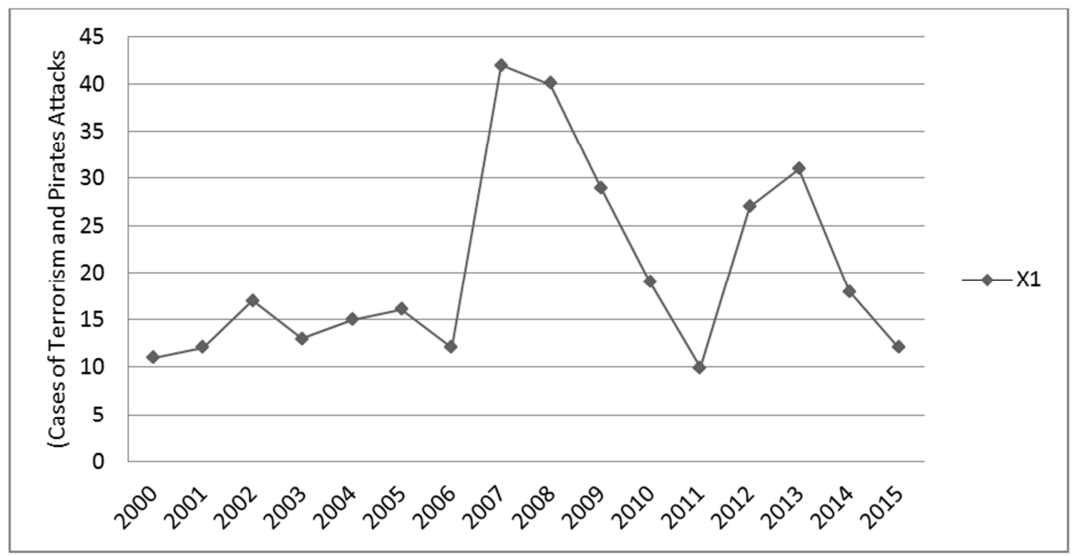

Figure 2. Trends in recorded cases of Maritime Terrorism and Piracy.

In figure 3, we note the correlation between incidence of terrorism and pirate attacks on total quantity of crude oil produced in offshore locations in Nigeria. As can be observed from the figure and consistent with our apriori expectation, there is an inverse relationship between the two variables. The low strength of association given the value of in equation (1), suggests that other variables (e.g. OPEC output quotas, market demand etc.) may have accounted for variations observed in outputs of crude oil production (X1).

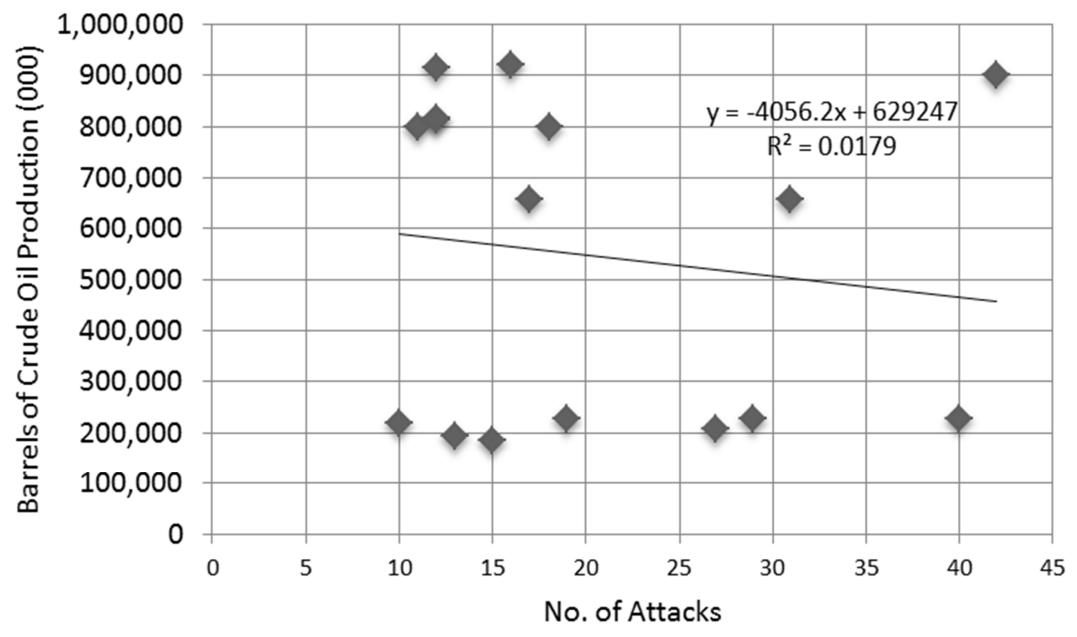

Figure 3. Relationship between Crude Produced and Number of Terror/Pirate Attacks. 


$$
\mathrm{y}_{1}=629247-4056.24 \mathrm{x}, \quad \mathrm{R}^{2}=0.0179
$$

In figure 4, an inverse relationship was also found to exist between quantity of crude oil in tanker vessels lost in offshore locations and terrorist/piracy incidence. The strength of relationship is low given the value of coefficient of variation in equation (2).

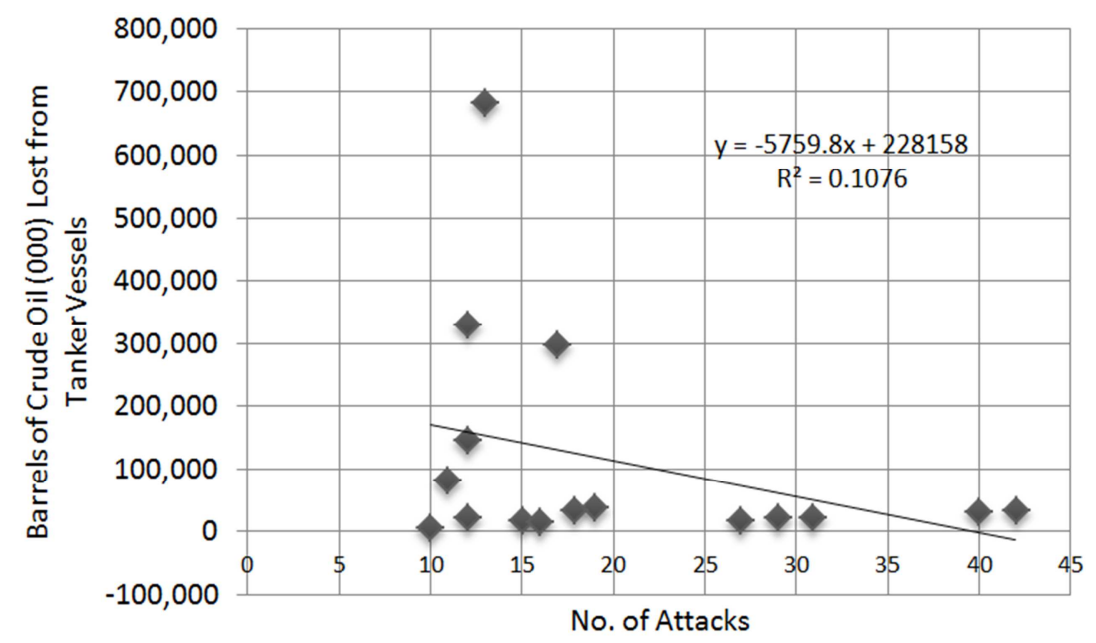

Figure 4. Relationship between Crude Losses from Tanker Vessels and Number of Terror/Pirate Attacks.

$$
\mathrm{y}_{2}=228158-5759.8 \mathrm{x}, \mathrm{R}^{2}=0.1076
$$

In figure 5 , it can be seen that the nature of relationship between quantity of fish caught or produced and terror/pirate attacks is similar to that observed in figures 3 and 4 . The weak relationship between the two variables (see equation (3)) may be linked to variables (omitted) accounting for variations in fish production in Nigeria.

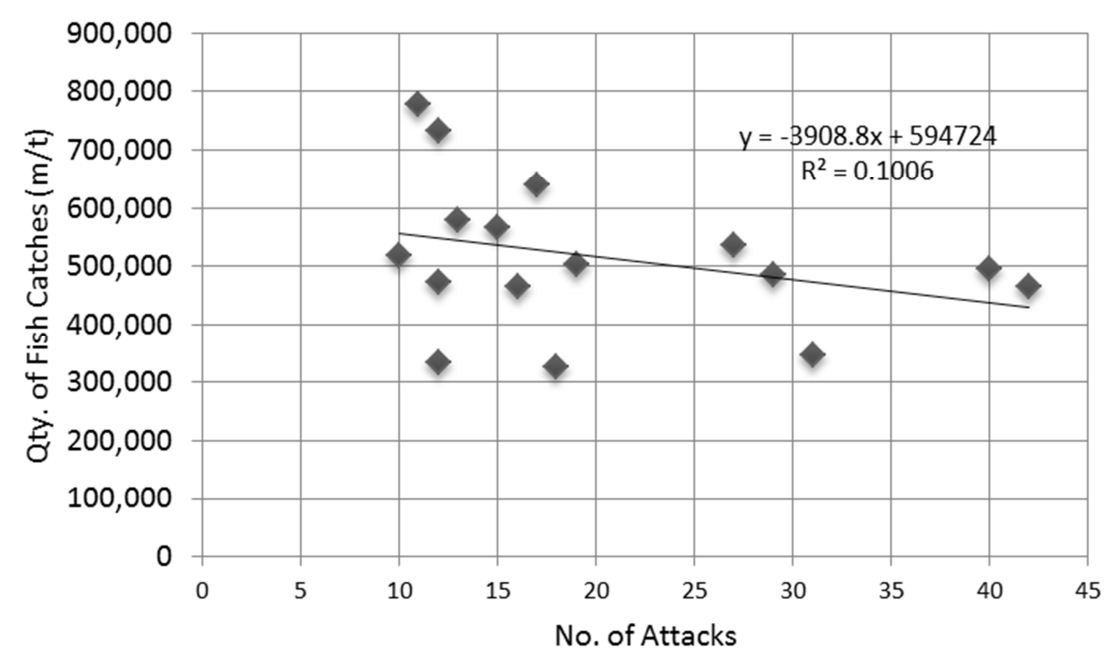

Figure 5. Relationship between Quantity of Fish Caught and Number of Terror/Pirate Attacks.

$$
\mathrm{y}_{3}=594724-3908.8 \mathrm{x}, \mathrm{R}^{2}=0.1006
$$

\section{Conclusion and Recommendations}

In this paper, we conducted an exploratory analysis of the relationship between incidence of maritime terrorism and piracy on some selected indices of maritime related economic activities. The indices considered in this study comprised volume of crude oil produced in offshore locations, quantity of crude oil lost (via tanker shipping) to terrorism acts and fish production. The findings from the analysis showed that there were significant negative effects of maritime terrorism and piracy acts on these economic activities. The significance of these findings suggests that the key drivers of Nigerian economy may continue to be negatively affected if adequate and sustained policy interventions are not introduced to check incidence of maritime related terrorism and piracy.

There is therefore the need for enhanced capacity building to provide robust maritime security to oil production, transportation and fishing activities especially in the Niger Delta region of Nigeria. Proper training of naval personnel 
and seafarers would provide them with necessary skills to be able to initiate adequate reaction to threats. If the maritime threats to the coastal areas of the Niger-Delta such as oil bunkering, attacks on oil installations, kidnapping and armed robbery are not brought under control, political stability and economic development of the region may continue to be undermined. This research was intended to serve a basis for a more in depth study of determinants of maritime terrorism and piracy and impacts on Nigerian economy. The analysis conducted here hence is exploratory in nature. Thus future studies on this theme should consider building a causal model incorporating more factors impacting maritime terrorism, piracy and Nigeria's blue economy.

\section{References}

[1] Donna, N. (2009). Nigeria: the 'other' maritime piracy hotbed, Journal of Ocean Technology IV (II), http://www.journalofoceantechnology.com.

[2] Essien, B. S. and Adongoi, T. (2015). Sea Piracy and Security Challenges of Maritime Business Operation in Bayelsa State, Nigeria: An Empirical Study. International Journal of Humanities and Social Science Vol. 5, No. 2.

[3] Hong, N. and Adolf K. Y Ng (2010). The International Legal Instruments in addressing piracy and Maritime terrorism: A Critical Review. Research in Transportation Economics 27 (2010), 51-60.

[4] Joubert, L. (2013). The extent of Maritime Terrorism and
Piracy: A comparative Analysis. Scientia Militaria, South African Journal of Military Studies, Vol. 41, NR 1, pp 111-137. Doi: $10.5787 / 41-1-1055$.

[5] Mansfield, C. T. (2008). Modern Piracy: the Impact on Maritime Security. Master of military studies, United States Marine Corps, Command and Staff College, Marine Corps Combat Development Command, Marine Corps University 2076 South Street, Quntio, Va, 22134-5068.

[6] Murphy, M. N. (2007). Suppression of Piracy and Maritime Terrorism. A Suitable Role for a Navy? Naval War College Review, Vol. 60, No 3, pp 22-45.

[7] Murphy, M. N. (2008). Small Boats, Weak States, Dirty Money: Piracy and Maritime Terrorism in the Modern World. New York: Columbia UP.

[8] Nelson, E. S. (2012). Maritime Terrorism and Piracy: Existing and Potential Threats, Global Security Studies, volume 3, Issue 1.

[9] Raymond, C. A. (2006). Maritime Terrorism in South East Asia: A risk Assessment. Terrorism and Political Violence, 18: 2, 239-257, Doi: 10.1080/095465505500383225.

[10] Singa, A. (2019). Maritime Terrorism in Asia: An Assessment. ORF Occasional paper, No. 215.

[11] Shortland, S. and Vothknecht, M. (2011). Combating "Maritime Terrorism" off the Coast of Somalia. European Journal of political Economy 27 (2011) S113-S151.

[12] Udensi, L. O, Etu, N. O and Chiele, E. O. (2014). National Security and Maritime Piracy in Nigeria: A Sociological Discourse. Humanities and Social Sciences Letters, 2014, 2 (1): 60-71. Journal homepage: htt://pakinsight.com. 